\title{
Gape size and evolution of diet in snakes: feeding ecology of erycine boas
}

\author{
Javier A. Rodríguez-Robles*, Christopher J. Bell† and Harry W. Greene \\ Museum of Vertebrate Zoology and Department of Integrative Biology, University of California, Berkeley, CA 94720-3160, U.S.A. \\ (Accepted 5 August 1998)
}

\begin{abstract}
The Macrostomata accounts for more than $85 \%$ of extant snakes and is characterized by increased mobility of the jaws and increased gape size. We used stomach contents of museum specimens and specific literature records to describe the food habits of a basal clade of macrostomatan snakes - the erycine boas (Erycinae) - with an emphasis on the North American Charina bottae. Mammals, lizards, birds, and squamate eggs composed $66 \%, 17 \%, 7 \%$, and 5\%, respectively, of the prey of $C$. bottae. Smaller $C$. bottae fed on squamate eggs and lizards, whereas larger snakes added mammals and birds to their diet, and ceased to take squamate eggs. Ten of 12 snakes with multiple prey had eaten nestling birds or mammals, and snakes that ate multiple prey were not significantly larger than those that had single prey. Charina trivirgata and C. reinhardtii also prey on mammals, whereas species of Eryx feed mainly on mammalian prey, but also eat lizards and occasionally birds. Evolutionarily more basal groups of snakes primarily feed on elongate prey, which suggests that innovations of the feeding apparatus of macrostomatans allowed these snakes to eat heavier and bulkier prey, particularly mammals. Erycines appeared and diversified at approximately the same geological time as rodents, suggesting that rodents perhaps constituted an abundant prey resource that favoured the diversification of early macrostomatans.
\end{abstract}

Key words: Boidae, Charina, Eryx, feeding ecology, fossil record, gape size

\section{INTRODUCTION}

For gape-limited predators such as snakes that swallow their prey whole, foraging success (i.e. mass eaten per unit time) likely increases with maximum ingestible prey size, other factors being equal (Forsman \& Lindell, 1993). Consequently, selection on traits influencing swallowing performance has probably been strong throughout the evolutionary history of snakes, as implied by the various morphological adaptations facilitating the ingestion of larger prey by more recently evolved ophidian clades (Greene, 1983a; Pough \& Groves, 1983; Cundall, 1987; Rieppel, 1988; Cundall \& Greene, in press). Studying the feeding biology of a particular group of snakes in a phylogenetic context and with an adequate fossil record should help elucidate factors that significantly influenced the evolutionary

*All correspondence to: Javier A. Rodríguez, Museum of Vertebrate Zoology, University of California, Berkeley, CA 94720-3160, U.S.A. E-mail: javier@socrates.berkeley.edu

$\dagger$ Present address: Department of Geological Sciences, University of Texas at Austin, Austin, TX 78712-1101, U.S.A.

$\$$ Present address: Section of Ecology and Systematics, Division of Biological Sciences, Cornell University, Ithaca, N.Y. 14853-2701, U.S.A. history of the group. With that broader goal, we used stomach contents of museum specimens and a survey of literature records to describe the feeding ecology of erycine boas, a basal clade of macrostomatan snakes.

Extant snakes are divided into two major clades: Scolecophidia (blindsnakes of three families) and Alethinophidia (all other snakes; Fig. 1). Macrostomata accounts for approx. 95\% of Alethinophidia and comprises boas and sand boas (Boidae), pythons (Pythonidae), Round Island boas (Bolyeriidae), dwarf boas (Tropidophiidae), Australasian filesnakes (Acrochordidae), vipers and pitvipers (Viperidae), stiletto snakes (Atractaspididae), racers, ratsnakes, watersnakes, etc. (Colubridae), and cobras, mambas, coralsnakes, seasnakes, etc. (Elapidae). The clade is characterized by, among other traits, morphological synapomorphies correlated with increased mobility of the jaws and increased gape size (Rieppel, 1988; Cundall $\&$ Greene, in press), hence the name Macrostomata ('big mouth').

Species of Erycinae, currently classified within Boidae (Fig. 1), are found in North America, Europe, Asia, and Africa. Traditional taxonomic treatments recognized two monotypic genera (Charina, Lichanura) in North 


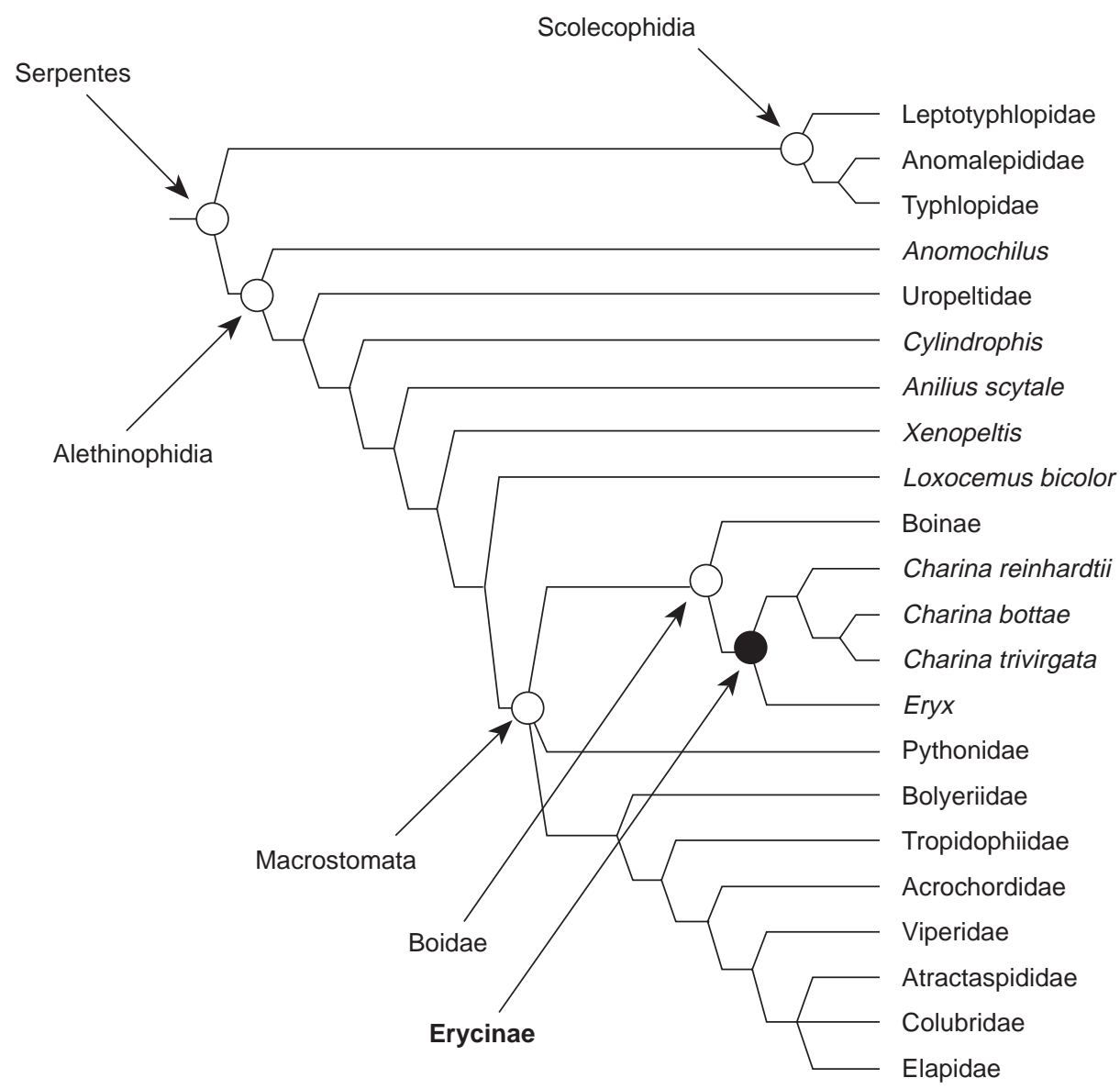

Fig. 1. Phylogenetic relationships among extant snakes, emphasizing those of erycine boas, Charina and Eryx (after Cadle, 1988; Cundall, Wallach \& Rossman, 1993; Kluge, 1993).

America, with Old World species placed in one or two genera (an all-encompassing Eryx or a restricted Eryx with Gongylophis to accommodate the species conicus, colubrinus, muelleri, and whitakeri; Das, 1991; Tokar, 1995, 1996). Kluge (1993) documented 16 synapomorphies placing the Calabar burrowing 'python' (traditionally placed in the monotypic Calabaria) within the Erycinae, and argued for the recognition of two named clades of erycines: Eryx to include the Old World sand boas (see also Szyndlar \& Schleich, 1994); and Charina to include the North American forms plus C. reinhardtii (Calabar burrowing boa), a taxonomic arrangement we follow herein (Fig. 1).

The two species of New World erycines, Charina bottae and C. trivirgata, are allopatric in western North America. Charina bottae (rubber boa) occurs from south-western Canada to southern California in the United States, and eastward from western California to northern Wyoming and Colorado (Stewart, 1977). Rubber boas occur in grassland, chaparral, and woodland (Nussbaum, Brodie \& Storm, 1983). They are good swimmers, burrowers, and climbers, and are largely crepuscular and nocturnal, but can also be active during the daytime (Ross, 1931; Stebbins, 1954; Peterson \& Dorcas, 1992). Charina trivirgata (rosy boa) ranges from southern California to the tip of Baja California, and eastward to western Arizona and the state of Sonora in northwestern Mexico (Yingling, 1982). Rosy boas occur in deserts and rocky shrubland and can be active at night, dusk, or in the daytime (Klauber, 1931; H. W. Greene, pers. obs.). Charina reinhardtii inhabits forested habitats of equatorial west and central Africa (Kluge, 1993). Fourteen species of Eryx (sand boas) occupy primarily deserts and steppes (although E. conicus also occurs in luxuriant forests) from northern and western Africa, northward to the Balkan peninsula and northern coasts of the Caspian Sea in eastern Europe, and eastward throughout India, Sri Lanka, western China and Mongolia (Wall, 1911; Sorensen, 1988; Kluge, 1993). Adult erycines are typically $<1 \mathrm{~m}$ in total length, although the maximum size for the extant species is approximately $1.3 \mathrm{~m}$ and $1.14 \mathrm{~kg}$ (for E. johnii; Chari, 1950).

Our goals here are to evaluate variation in taxonomic composition of diets and erycine foraging tactics, with an emphasis on $C$. bottae. We also rely on the excellent fossil record of erycines and of rodents to gain a historical perspective on how prey characteristics may have influenced evolutionary innovations in the trophic apparatus of macrostomatans. 
Table 1. Prey eaten by Charina bottae. 'Perognathus (sensu lato) sp.' refers to Chaetodipus or Perognathus (sensu stricto). 'Frequency' refers to the number of times each prey taxon was found in the entire sample; numbers in parentheses indicate the number of snakes that ate that particular prey

\begin{tabular}{|c|c|c|c|}
\hline Prey taxon & Frequency & $\begin{array}{l}\text { Percentage of total } \\
\text { no. of prey }\end{array}$ & Source \\
\hline \multicolumn{4}{|l|}{ Gastropoda } \\
\hline \multicolumn{4}{|l|}{ Stylommatophora } \\
\hline \multicolumn{4}{|l|}{ Arionidae } \\
\hline Ariolimax columbianus & $1(1)$ & 1.1 & G. Anderson, pers. comm. \\
\hline \multicolumn{4}{|l|}{ Aves } \\
\hline \multicolumn{4}{|l|}{ Passeriformes } \\
\hline \multicolumn{4}{|l|}{ Paridae } \\
\hline Parus rufescens & $6(1)$ & 6.7 & Copper, Ohmart \& Dahlsten, 1978 \\
\hline \multicolumn{4}{|l|}{ Mammalia } \\
\hline \multicolumn{4}{|l|}{ Insectivora } \\
\hline \multicolumn{4}{|l|}{ Talpidae } \\
\hline Scapanus latimanus & $3(1)$ & 3.4 & This study \\
\hline cf. Scapanus latimanus & $3(1)$ & 3.4 & This study \\
\hline Unidentified talpid & $2(1)$ & 2.2 & This study \\
\hline \multicolumn{4}{|l|}{ Soricidae } \\
\hline Sorex sp. & $2(2)$ & 2.2 & This study; Koch \& Peterson, 1995 \\
\hline \multicolumn{4}{|l|}{ Rodentia } \\
\hline \multicolumn{4}{|l|}{ Dipodidae } \\
\hline Zapus princeps & $1(1)$ & 1.1 & Stebbins, 1954 \\
\hline \multicolumn{4}{|l|}{ Geomyidae } \\
\hline Thomomys talpoides & $5(1)$ & 5.6 & Bartholomew \& Lleyson, 1993 \\
\hline \multicolumn{4}{|l|}{ Heteromyidae } \\
\hline Perognathus (sensu lato) sp. & $1(1)$ & 1.1 & This study \\
\hline \multicolumn{4}{|l|}{ Muridae } \\
\hline Microtus californicus & $1(1)$ & 1.1 & This study \\
\hline Microtus longicaudus & $1(1)$ & 1.1 & Brunson \& Demaree, 1951 \\
\hline cf. Microtus montanus & $1(1)$ & 1.1 & Fitch, 1936 \\
\hline Peromyscus maniculatus & $6(1)$ & 6.7 & This study \\
\hline Peromyscus cf. P. maniculatus & 4(1) & 4.5 & This study \\
\hline Peromyscus sp. & $1(1)$ & 1.1 & This study \\
\hline Unidentified rodent & $13(5)$ & 14.6 & $\begin{array}{l}\text { This study; Van Denburgh, 1922; } \\
\text { Agerter, 1932; Logier, 1932; } \\
\text { Tanner \& Tanner, } 1939\end{array}$ \\
\hline Unidentified mammal & $15(5)$ & 16.9 & This study; Cope, 1900 \\
\hline \multicolumn{4}{|l|}{ Reptilia } \\
\hline \multicolumn{4}{|l|}{ Squamata } \\
\hline \multicolumn{4}{|l|}{ Anguidae } \\
\hline Elgaria coerulea & $1(1)$ & 1.1 & P. Gregory, pers. comm. \\
\hline Elgaria $\mathrm{sp}$ & $6(6)$ & 6.7 & This study; Stebbins, 1954 \\
\hline \multicolumn{4}{|l|}{ Phrynosomatidae } \\
\hline Sceloporus occidentalis & $4(2)$ & 4.5 & This study; Van Denburgh, 1922 \\
\hline Sceloporus sp. & $3(3)$ & 3.4 & This study; Cope, 1900 \\
\hline Unidentified lizard & $1(1)$ & 1.1 & This study \\
\hline \multicolumn{4}{|l|}{ Squamate eggs } \\
\hline 1 & $1(1)$ & 1.1 & This study \\
\hline 2 & $1(1)$ & 1.1 & This study \\
\hline 4 & $1(1)$ & 1.1 & This study \\
\hline $6 \mathrm{cf}$. Sceloporus graciosus eggs & $1(1)$ & 1.1 & R. Staub, pers. comm. \\
\hline Unidentified animal & $4(4)$ & 4.5 & This study \\
\hline Total & 89 & & \\
\hline
\end{tabular}

\section{METHODS}

We examined 249 and 84 specimens of Charina bottae and C. trivirgata, respectively, in the California Academy of Sciences (CAS), San Francisco and the Museum of Vertebrate Zoology (MVZ), University of California, Berkeley. We checked for stomach contents by making a midventral incision in preserved specimens, avoiding only type specimens and fragile individuals. Whenever possible, for each snake with prey we recorded locality data, body size (snout-vent length SVL $\pm 1 \mathrm{~cm})$, body mass $( \pm 0.1 \mathrm{~g})$, and minimum number of items in the stomach. All squamate eggs in a single stomach were counted as one item because they may represent a feeding event at the same site and because sometimes their exact number was impossible 
Table 2. Records of Charina bottae that consumed multiple prey

\begin{tabular}{lll}
\hline Museum catalogue number/source & Snake snout-vent length $(\mathrm{cm})$ & No. of prey \\
\hline CAS 28323 & 52.2 & 2 Sceloporus occidentalis \\
Van Denburgh, 1922 & - & 2 Sceloporus occidentalis \\
Copper et al., 1978 & 52.8 & 6 Parus rufescens \\
MVZ 193419 & 39.7 & 3 Scapanus latimanus \\
CAS 201590 & 56.0 & 3 cf. Scapanus latimanus \\
MVZ 61915 & 50.9 & 2 unidentified talpids \\
CAS-SU 4189 & 39.2 & 6 Peromyscus maniculatus \\
MVZ 140672 & 31.8 & 4 Peromyscus cf. P. maniculatus \\
Bartholomew \& Lleyson, 1993 & 40.0 & 5 Thomomys talpoides \\
Van Denburgh, 1922 & - & 6 unidentified rodents \\
Logier, 1932 & - & 2 unidentified rodents \\
Tanner \& Tanner, 1939 & - & 3 unidentified rodents \\
\hline
\end{tabular}

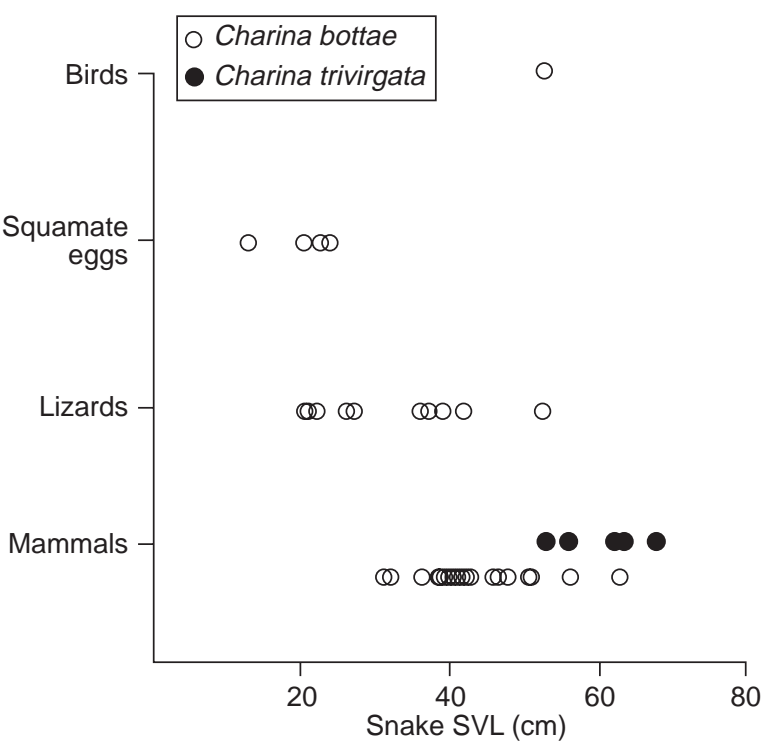

Fig. 2. Relationship between prey category and snake body size (SVL) in Charina bottae $(n=41)$ and C. trivirgata $(n=7)$.

to determine. Direction of ingestion (inferred from orientation in the stomach) and order of ingestion of multiple items were recorded as far as possible. Taxonomic identifications were made by comparison with specimens in the MVZ, whenever possible with specimens from the same county or state from which the snake was taken. Partially digested prey, especially those representing mammals, were carefully examined for diagnostic elements. Hair mats frequently contained complete or partial dentitions or isolated teeth that could be identified to genus or species. We weighed snakes and their intact or slightly digested prey after blotting and draining them briefly on paper towels to remove excess fluid.

Our data set also incorporates published dietary records (Table 1). We took care to account for redundancy among literature records (Cope, 1900 with Shaw \& Campbell, 1974), and excluded accounts of prey taken in captivity (Lewis, 1946; Linder, 1963; Shaw \& Campbell, 1974; Peabody, Johnson \& Brodie, 1975) or under otherwise artificial circumstances (Borell, 1931;
Macey, 1983). Values given are means \pm 1 SD and $P$-values are 2-tailed.

\section{RESULTS}

Forty Charina bottae $(\mathrm{SVL}=39.2 \pm 10.6 \mathrm{~cm}$, range $=12.7-56.0 \mathrm{~cm}, n=40$; body mass $=54.3 \pm 37.8 \mathrm{~g}$, range $=3.5-150.1 \mathrm{~g}, n=40), 16.1 \%$ of the specimens we examined, contained 54 at least partly identifiable prey items. Including 35 published and unpublished dietary records (from 17 snakes), 59 (66.3\%) of 89 prey eaten by $C$. bottae were mammals, $17(16.9 \%)$ were 'lizards' (i.e. squamate reptiles other than snakes and amphisbaenians), six $(6.7 \%)$ were birds, four $(4.5 \%)$ were squamate eggs, one $(1.1 \%)$ was a slug, and four were unidentified animals (Table 1; the high number of unidentified lizards, birds, and mammals is the result of stomach contents that consisted exclusively of a few scales, feathers, or clumps of hair with no cranial material). Published dietary records for which we could not determine the frequency of consumption by C. bottae included Elgaria coerulea (northern alligator lizard), unidentified birds, Eutamias sp. (chipmunks), and Zapus princeps (jumping mouse; Weeks \& Davis, 1963). Shrews have been noted to be commonly eaten by rubber boas (Nussbaum et al., 1983), but we found two records only among 89 prey. Forty-five $(78.9 \%)$ of 57 C. bottae with food contained a single prey, four $(7.0 \%)$ snakes had two items, three $(5.3 \%)$ had ingested three prey, one (1.8\%) had four, another one had five, and three rubber boas contained six prey each (Table 2). Twelve of $48 \quad(25 \%)$ snakes large enough (i.e. $S V L \geq 29.2 \mathrm{~cm}$ ) to eat mammals or birds had multiple prey. There was no significant difference in body size between snakes that had a single prey $(\mathrm{SVL}=38.1 \pm 11.4 \mathrm{~cm}$, range $=12.7-62.6 \mathrm{~cm}, n=37)$ and those that contained multiple prey (SVL $=45.3 \pm 8.7 \mathrm{~cm}$, range $=31.8-56.0 \mathrm{~cm}, n=8$; singlefactor ANOVA, $\left.F_{(1,43)}=2.83, P=0.10\right)$. There was a significant difference in SVL among rubber boas that ate mammals $(\mathrm{SVL}=44.2 \pm 7.4 \mathrm{~cm}$, range $=31.0$ $62.6 \mathrm{~cm}, \quad n=26), \quad$ lizards $\quad(\mathrm{SVL}=32.2 \pm 10.6 \mathrm{~cm}$, range $=20.5-52.2 \mathrm{~cm}, \quad n=10), \quad$ and squamate eggs 


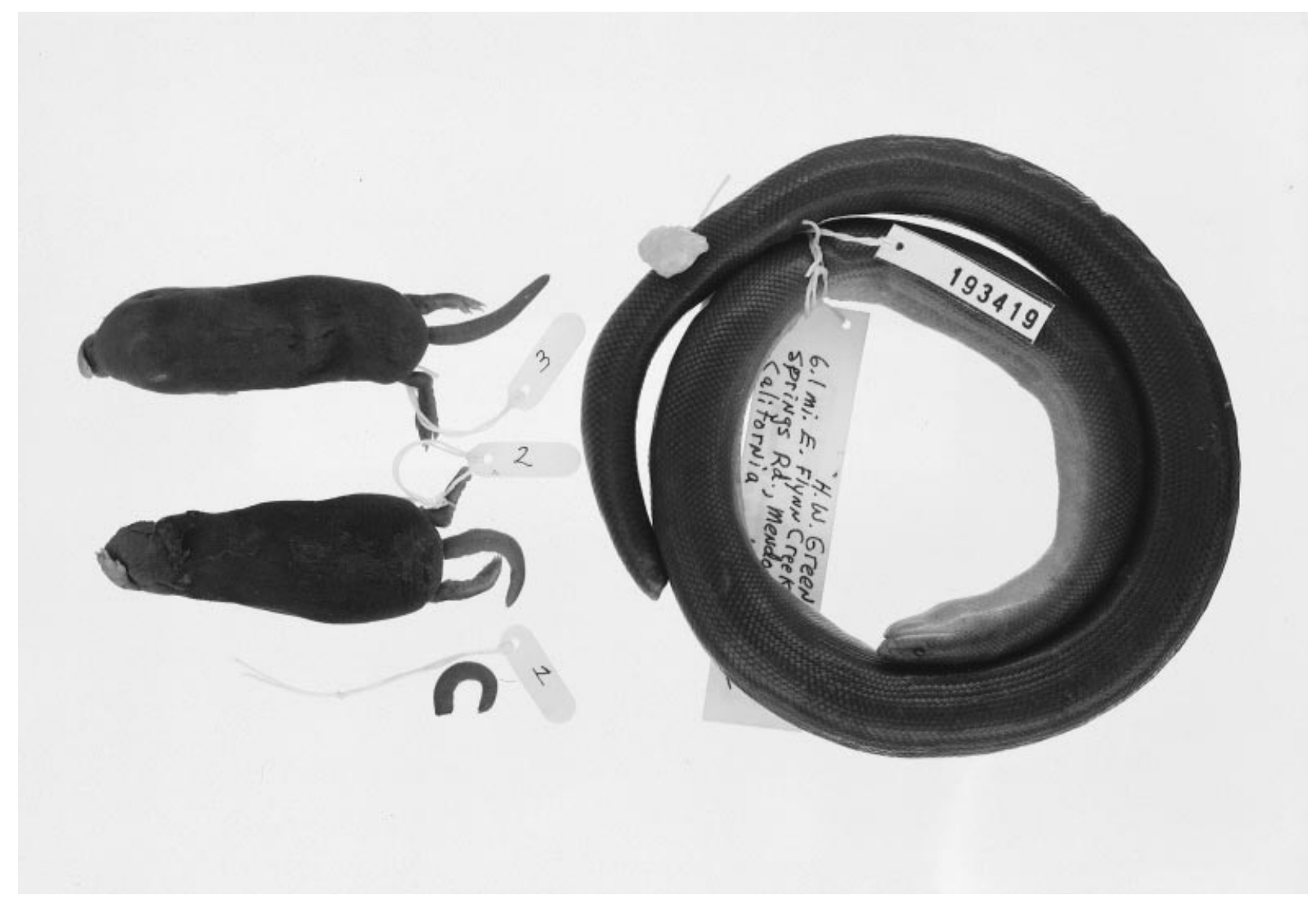

Fig. 3. Charina bottae (MVZ 193419), snout-vent length $39.7 \mathrm{~cm}, 52.5 \mathrm{~g}$, from California (USA), with three broad-footed moles (Scapanus latimanus). Numbers next or attached to individual prey (or remains) indicate the order in which they were ingested.

$(\mathrm{SVL}=19.7 \pm 4.9 \mathrm{~cm}, \quad$ range $=12.7-23.6 \mathrm{~cm}, \quad n=4$ single-factor ANOVA, $F_{(2,37)}=20.18, \quad P<0.0001$; Fig. 2), and multiple comparison tests indicated that the differences among the three groups of snakes were significant.

Sixteen prey were swallowed head-first and six were ingested tail-first (16/6: [predicted] 11/11, $G$-test of independence with Williams' correction, $G=2.34$, 1 d.f., $P=0.13)$. Three lizards were ingested head-first and two were ingested tail-first, in comparison with 13 mammals swallowed head-first and four ingested tail-first (Fisher's exact test, $P=0.59$ ).

We could only reliably estimate prey mass of six nestling deer mice Peromyscus maniculatus (individual prey masses $=4.2,5.4,5.9,6.0,5.9,6.0 \mathrm{~g}$ ) eaten by a single $C$. bottae (CAS-SU 4189, $51.7 \mathrm{~g}$ ). Relative prey mass (prey mass/snake mass) for the combined mice was 0.65. Prey mass of two of three Scapanus latimanus (broad-footed mole) taken by another C. bottae (MVZ 193419, 52.5 g; Fig. 3) was 4.9 and 5.6 g, which, assuming that the first item swallowed had a mass equal to the average of that of the other two moles, suggests that relative prey mass for the three prey was approximately 0.3 .

Eight Charina trivirgata $\quad(\mathrm{SVL}=59.7 \pm 5.7 \mathrm{~cm}$, range $=53.0-67.7 \mathrm{~cm}, \quad n=7 ; \quad$ body $\operatorname{mass}=170.7 \pm$ $39.4 \mathrm{~g}$, range $=129.1-243.7 \mathrm{~g}, n=7), 9.5 \%$ of the speci- mens we examined, contained single mammalian prey: one P. maniculatus, one Dipodomys sp., one Perognathus (sensu lato) sp., two unidentified rodents, and three unidentified mammals. Three prey were swallowed head-first and one was ingested tail-first. The only published dietary records we found for C. trivirgata were one adult Dipodomys sp. (kangaroo rat), one sciurid rodent (ground squirrel), four young rabbits in the same snake (Merker \& Merker, 1995), and an unidentified mammal (Klauber, 1933). Thus, 12 C. trivirgata contained 15 prey, all mammals. Records of natural diet for two $C$. reinhardtii include only nestling murid rodents, one Dasymys incomtus (shaggy swamp rat) in one snake, and two Hybomys univittatus (one-striped forest mouse) in another (Gartlan \& Struhsaker, 1971).

The natural diets of species of Eryx generally resemble those of the three species of Charina. Specific prey items include a gecko, birds, and a naked mole-rat in E. colubrinus; a lizard, several birds, and squirrels and other mammals in E. conicus; a vole in E. elegans; rodents in E. jaculus; geckos in E. jayakari; a shrew and rodents in E. johnii; several lizards, birds, and rodents, and a bat in E. miliaris; and lizards, birds, and several rodents in E. tataricus (Table 3). Although precise data are lacking, individual E. conicus with total lengths as small as $42 \mathrm{~cm}$ have eaten adult Funambulus palmarum 
Table 3. Dietary records for Eryx colubrinus, E. conicus, E. elegans, E. jaculus, E. jayakari, E. johnii, E. miliaris, and E. tataricus. Source: 1 =Wall, 1911; 2 = Levett-Yeats, 1914; 3 = Powell, 1914; 4 = Pitman, 1958; 5= Bogdanov, 1962; 6 = Nikol'skii, 1964; 7 = Bogdanov, 1965; 8 = Minton, 1966; 9 = Bogdanov, 1970; $10=$ Sharma \& Vazirani, 1977; 11 Khajuria \& Agrawal, 1981; $12=$ Shammakov, 1981; $13=$ Daniel, 1983; $14=$ Ataev, 1985; $15=$ Gasperetti, 1988; $16=$ Prakash, 1988; $17=$ Braude, 1991

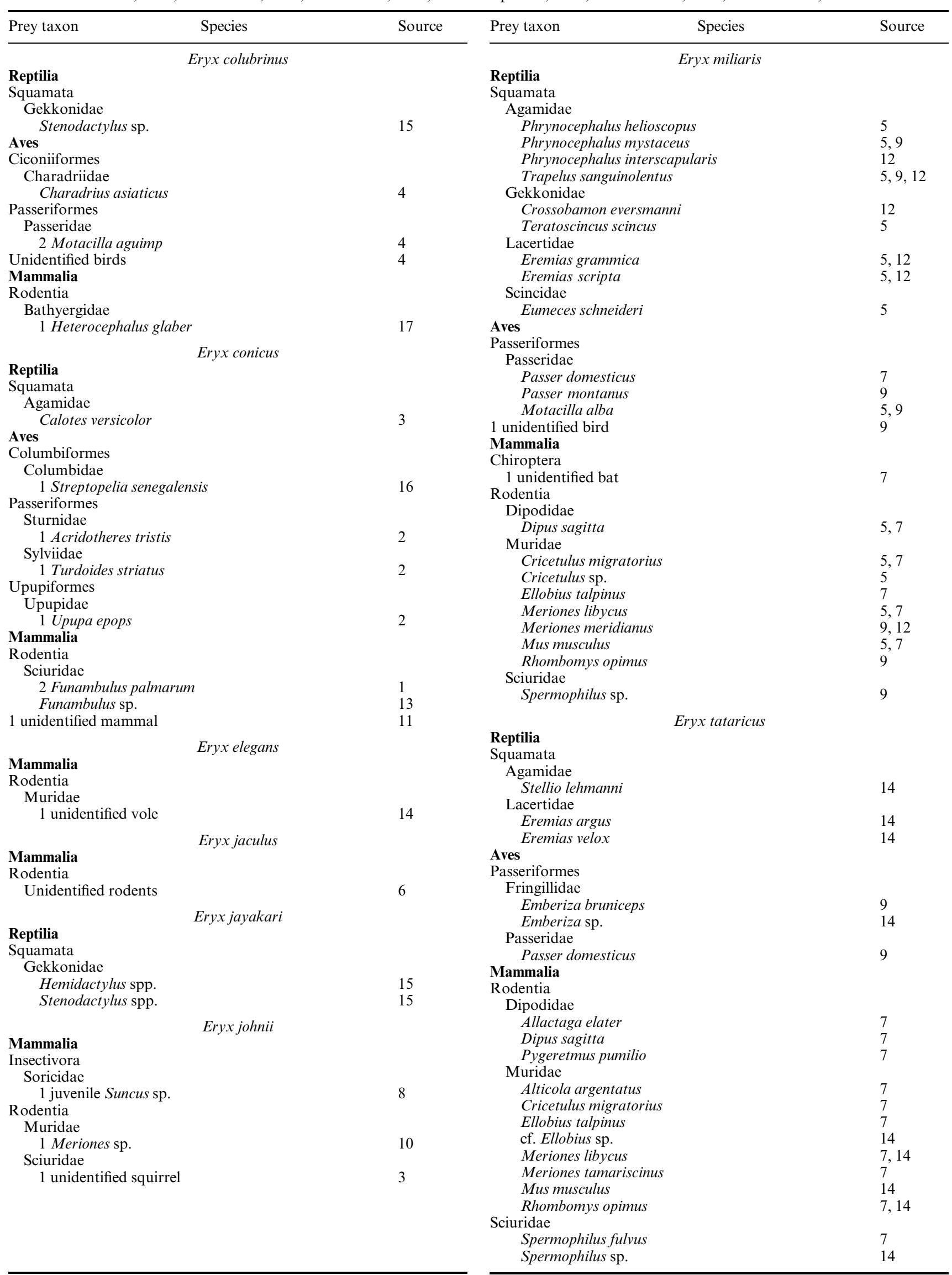


(three-striped palm squirrel; head-body length $12-$ $19 \mathrm{~cm}$, mass $100-160 \mathrm{~g}$ ), and thus sometimes take prey that approach their own body mass (Wall, 1911).

\section{DISCUSSION}

Our study suggests that small $C$. bottae feed primarily on squamate eggs and lizards; larger snakes cease to eat squamate eggs and add birds and various species of mammals to their diets. Similar ontogenetic dietary shifts from ectotherms to endotherms are widespread among other snakes, including various boines (Henderson et al., 1987; Henderson, 1993), pythons (Shine \& Slip, 1990), vipers (Fitch, 1960; Shine et al., 1998), colubrids (Mushinsky, Hebrard \& Vodopich, 1982; Greene, 1989; Rodríguez-Robles, Bell \& Greene, 1999), and elapids (Shine, 1980). Such shifts presumably reflect the absolutely larger gape required to consume even the smallest mammals and birds (e.g. the head of a small $C$. bottae [MVZ 43608], SVL $=29.2 \mathrm{~cm}$, is only $0.7 \mathrm{~cm}$ in maximum width). Predation on clumped nestlings is clearly a significant aspect of the foraging biology of adult $C$. bottae (all multiple items in 12 rubber boas were individuals of the same prey species, and in at least seven cases were nestlings), and the collective body mass of a litter may well exceed that of an adult of the same species. The relatively high incidence of tail-first prey ingestion by $C$. bottae perhaps reflects predation on relatively small items, as nestlings have low relative prey mass ratios and small diameters compared to snake head size (cf. Greene, 1976; Rodríguez-Robles \& Leal, 1993). Our findings for C. trivirgata and Old World erycines imply diets generally similar to that of $C$. bottae, including at least occasional consumption of both nestling mammals and of relatively bulky, heavy prey.

Indirect evidence and fortuitous field observations document both wide-foraging and ambush-hunting tactics among erycines. Nestling birds and rodents are necessarily sedentary, so $C$. bottae and $C$. reinhardtii must encounter those prey by wide-foraging rather than ambush; in fact, these two species have been seen crawling into nests (Ross, 1931; Gartlan \& Struhsaker, 1971; Copper, Ohmart \& Dahlsten, 1978). An observation of a C. trivirgata coiled above a Neotoma sp. (woodrat) nest (Klauber, 1924) may imply ambush tactics by rosy boas. Eryx conicus and E. jaculus use both wide-foraging and ambush tactics in hunting prey - the former species was observed to conceal itself at the base of trees to seize passing palm squirrels, and within a hole to capture doves feeding on a nearby dung heap (Daniel, 1983; Prakash, 1988; Tokar, 1995). Erycines thus may prove fruitful subjects for exploring the costs and benefits of alternative foraging modes (see Huey \& Pianka, 1981; Secor \& Nagy, 1994), and field studies may determine if these snakes capture agamid lizards and other diurnally active species by ambush-hunting or by wide-foraging for those prey in their nocturnal retreats.
Comparisons with immediate outgroups, the basal alethinophidians (i.e. Anomochilus, uropeltids, Cylindrophis, Anilius scytale, Xenopeltis, Loxocemus bicolor; Fig. 1), provide insights into the early evolution of erycines. Most basal alethinophidians have strongly constrained gapes due to retention of a primitive jaw anatomy (Cundall \& Greene, in press) and therefore primarily eat elongate prey (e.g. eels, caecilians, limbless squamates, earthworms; Greene, 1983a, 1997; VallsMoraes \& Yuki, 1998). Observations on some successive extant outgroups to Macrostomata (L. bicolor - Mora, 1991; scolecophidians - Gehlbach, Watkins \& Kroll, 1971; Webb \& Shine, 1992; varanoid lizards - Pregill, Gauthier \& Greene, 1986) suggest that snakes primitively used wide-foraging rather than ambush-hunting techniques. In contrast, boines, pythons, and more derived lineages (e.g. pitvipers) primarily rely on ambush-hunting (Greene, 1983b; Slip \& Shine, 1988; Greene, 1992; Secor \& Nagy, 1994) and often take prey that are both heavy and bulky (Greene, 1983b; Shine \& Slip, 1990), which implies that those two innovations may have characterized the feeding biology of ancestral macrostomatans. Erycines use both ambush-hunting and the primitive wide-foraging behaviour and take heavy, bulky prey (which sometimes approach the snake's own mass) as well as light-weight, but bulky prey (i.e. nestling mammals and birds). Provided that erycines arose within a clade including boines and pythons (Fig. 1), frequent predation on nestling mammals and reversal to wide-foraging by erycines represent subsequent modifications of the feeding biology characteristic of the earliest macrostomatans.

The fossil record of erycines and rodents is consistent with our scenario of early macrostomatan evolution. The 12 described genera of fossil North American erycines, some of them of questionable status, consist almost entirely of isolated vertebrae or short sequences of articulated vertebrae (Holman, 1979; Harding \& Holman, 1982; but see Breithaupt \& Duvall, 1986). If Helagras is an erycine, the fossil record for this group extends to the Early Paleocene (approx. 65 million years ago [Mya]). Cheilophis, Huberophis, Lithophis, and one species each of Calamagras and Ogmophis are known from the Eocene (54-38 Mya). A rich erycine fossil history from widely scattered Eurasian and Middle Eastern localities dates from the Eocene (Hoffstetter \& Rage, 1972; Milner, 1986; Rage, 1987; Thomas et al., 1991; Rage \& Augé, 1993; Szyndlar and Schleich, 1994). The origin of erycines has been disputed, but based on his phylogenetic hypothesis for these snakes, Kluge (1993) suggested that the clade radiated initially in the Old World. Although rodents first appear in the fossil record of many Asian and North American localities in the Late Paleocene (57-54 Mya), phylogeneticallyderived biogeographic reconstructions and the occurrence of older basal rodents (or rodent sister taxa, depending upon the definition of Rodentia) in Asia unambiguously support an Asiatic origin for the group (Vianey-Liaud, 1985; Li et al., 1987; Dashzeveg, 1990, Meng et al., 1994; McKenna \& Bell, 1997; Beard, 1998). 
Available evidence thus indicates a roughly contemporaneous origin for erycine boas and rodents, during widespread conversion from forests to steppes and other more open environments (Behrensmeyer et al., 1992). We suggest that the early radiation of rodents, with their rapid life cycles and exuberant fecundity, may have provided special circumstances of prey size, shape, and abundance that favoured the diversification of the ancestors of modern erycines.

\section{Acknowledgements}

We thank J. V. Vindum and R. C. Drewes (CAS) for allowing us to examine specimens; G. Anderson, P. T. Gregory, and R. Staub for their unpublished observations on the diet of Charina bottae; T. J. Papenfuss and B. M. Waggoner for providing and translating Russian literature; P. Rasmussen, N. K. Johnson, and J. L. Patton for clarifying avian and mammalian taxonomy; and J. V. Vindum, R. C. Drewes, E. Hekkala, and M. Koo for their valuable help during our numerous visits to CAS. This research was partly funded by a Mentored Research Award from the Office of the Dean of the Graduate Division and by an Annie $M$. Alexander Fellowship from the Museum of Vertebrate Zoology, University of California, Berkeley, to JAR; by a Samuel P. Welles and Dorothy Hampton Welles Award from the Museum of Paleontology, University of California, Berkeley, to CJB; and by a grant from the National Science Foundation to HWG.

\section{REFERENCES}

Agerter, K. S. (1932). A record snake found. Yellowstone Nat. Notes 9: 33-34.

Ataev, C. A. (1985). Reptiles of the mountains of Turkmenistan. Ashkhabad, Turkmenistan: Ylym. [In Russian.]

Bartholomew, B. D. \& Lleyson, C. (1993). Natural history notes: Charina bottae (rubber boa). Food. Herpetol. Rev. 24: 105106.

Beard, K. C. (1998). East of Eden: Asia as an important center of taxonomic origination in mammalian evolution. In Dawn of the age of mammals in Asia: 5-39. Beard, K. C. \& Dawson, M. R. (Eds). Bull. Carnegie Mus. Nat. Hist. No. 34

Behrensmeyer, A. K., Damuth, J. D., DiMichele, W. A., Potts, R., Sues, H.-D. \& Wing, S. L. (Eds). (1992). Terrestrial ecosystems through time: evolutionary paleoecology of terrestrial plants and animals. Chicago: University of Chicago Press.

Bogdanov, O. P. (1962). Reptiles of Turkmenia. Ashkhabad, Turkmenistan: Academy of Sciences of the Turkmenian Soviet Socialist Republic. [In Russian.]

Bogdanov, O. P. (1965). Ecology of reptiles of central Asia. Tashkent: Nauka Publishing of the Uzbek Soviet Socialist Republic. [In Russian.]

Bogdanov, O. P. (1970). Birds as food items of reptiles. In The living world of Turkmenia (land vertebrates): 123-133. Gladkov, N. A., Tashliev, A. G., Bannikov, A. G., Dement'ev G. P. \& Sopyev, O. S. (Eds). Ashkhabad, Turkmenistan: Ylym. [In Russian.]

Borell, A. E. (1931). Notes on food habits of a rubber snake. Copeia 1931: 141.
Braude, S. H. (1991). Which naked mole-rats volcano? In The biology of the naked mole-rat: 185-194. Sherman, P. W., Jarvis, J. U. M. \& Alexander, R. D. (Eds). Princeton: Princeton University Press.

Breithaupt, B. H. \& Duvall, D. (1986). The oldest record of serpent aggregation. Lethaia 19: 181-185.

Brunson, R. B. \& Demaree, H. A., Jr. (1951). The herpetology of the Mission Mountains, Montana. Copeia 1951: 306-308.

Cadle, J. E. 1988. Phylogenetic relationships among advanced snakes: a molecular perspective. Univ. Calif. Publ. Zool. 119: $1-77$.

Chari, V. K. (1950). The record black earth boa [Eryx johni (Russell)]. J. Bombay Nat. Hist. Soc. 49: 127.

Cope, E. D. (1900). The crocodilians, lizards, and snakes of North America. Report of the U.S. National Museum for 1898: 153-1294.

Copper, W. A., Ohmart, C. P. \& Dahlsten, D. L. (1978). Predation by a rubber boa on chestnut-backed chickadees in an artificial nesting site. West. Birds 9: 41-42.

Cundall, D. (1987). Functional morphology. In Snakes: ecology and evolutionary biology: 106-140. Seigel, R. A., Collins, J. T. \& Novak, S. S. (Eds). New York: McGraw-Hill Publishing Company.

Cundall, D. \& Greene, H. W. (In press.) Feeding in snakes. In Feeding in tetrapod vertebrates. Form, function, phylogeny. Schwenk, K. (Ed.). San Diego: Academic Press.

Cundall, D., Wallach, V. \& Rossman, D. A. (1993). The systematic relationships of the snake genus Anomochilus. Zool. J. Linn. Soc. 109: 275-299.

Daniel, J. C. (1983). The book on Indian reptiles. Bombay, India: Bombay Natural History Society.

Das, I. (1991). A new species of Eryx (Boidae: Serpentes: Squamata) from south-western India. J. Bombay Nat. Hist. Soc. 88: 92-97.

Dashzeveg, D. (1990). The earliest rodents (Rodentia, Ctenodactyloidea) of Central Asia. Acta Zool. Cracov. 33: 11-35.

Fitch, H. S. (1936). Amphibians and reptiles of the Rogue River Basin, Oregon. Am. Midl. Nat. 17: 634-652.

Fitch, H. S. (1960). Autecology of the copperhead. Univ. Kansas Publ. Mus. Nat. Hist. 13: 85-288.

Forsman, A. \& Lindell, L. E. (1993). The advantage of a big head: swallowing performance in adders, Vipera berus. Funct. Ecol. 7: 183-189.

Gartlan, J. S. \& Struhsaker, T. T. (1971). Notes on the habits of the Calabar ground python (Calabaria reinhardtii Schlegel) in Cameroon, West Africa. Br. J. Herpetol. 4: 201-202.

Gasperetti, J. (1988). Snakes of Arabia. In Fauna of Saudi Arabia 9: 169-450. Büttiker, W. \& Krupp, F. (Eds). Riyadh, Saudi Arabia: National Commission for Wildlife Conservation and Development.

Gehlbach, F. R., Watkins, J. F., II \& Kroll, J. C. (1971). Pheromone trail-following studies of typhlopid, leptotyphlopid, anc colubrid snakes. Behaviour 40: 282-294.

Greene, H. W. (1976). Scale overlap, a directional sign stimulus for prey ingestion by ophiophagous snakes. Z. Tierpsychol. 41: $113-120$.

Greene, H. W. (1983a). Dietary correlates of the origin and radiation of snakes. Am. Zool. 23: 431-441.

Greene, H. W. (1983b). Boa constrictor (boa, béquer, boa constrictor). In Costa Rican natural history: 380-382. Janzen, D. H. (Ed.) Chicago: University of Chicago Press.

Greene, H. W. (1989). Ecological, evolutionary, and conservation implications of feeding biology in Old World cat snakes, genus Boiga (Colubridae). Proc. Calif. Acad. Sci. 46: 193207.

Greene, H. W. (1992). The ecological and behavioral context for pitviper evolution. In Biology of the pitvipers: 107-117. Campbell, J. A. \& Brodie, E. D., Jr. (Eds). Tyler, Texas: Selva. 
Greene, H. W. (1997). Snakes: the evolution of mystery in nature. Berkeley: University of California Press.

Harding, J. H. \& Holman, J. A. (1982). The paleohistory of snakes in North America - a brief review. Bull. Chicago Herpetol. Soc. 17: 33-45.

Henderson, R. W. (1993). Foraging and diet in West Indian Corallus enydris (Serpentes: Boidae). J. Herpetol. 27: 24-28.

Henderson, R. W., Noeske-Hallin, T. A., Ottenwalder, J. A. \& Schwartz, A. (1987). On the diet of the boa Epicrates striatus on Hispaniola, with notes on E. fordi and E. gracilis. Amphib.Reptilia 8: 251-258.

Hoffstetter, R. \& Rage, J.-C. (1972). Les Erycinae fossiles de France. Compréhension et histoire de la sous-famille. Ann. Paléontol. (Vertébr.) 58: 81-124.

Holman, J. A. (1979). A review of North American Tertiary snakes. Publ. Mus. Mich. State Univ., Paleontol. Ser. 1: 203260.

Huey, R. B. \& Pianka, E. R. (1981). Ecological consequences of foraging mode. Ecology 62: 991-999.

Khajuria, H. \& Agrawal, H. P. (1981). Studies on wild life of Narbada Valley-Part II. Reptilia. Rec. Zool. Surv. India 78: 2136.

Klauber, L. M. (1924). Notes on the distribution of snakes in San Diego County, California. Bull. Zool. Soc. San Diego 1: 1-23.

Klauber, L. M. (1931). A new subspecies of the California boa, with notes on the genus Lichanura. Trans. San Diego Soc. Nat. Hist. 6: 305-318.

Klauber, L. M. (1933). Notes on Lichanura. Copeia 1933: 214 215.

Kluge, A. (1993). Calabaria and the phylogeny of erycine snakes. Zool. J. Linn. Soc. 107: 293-351.

Koch, E. D. \& Peterson, C. R. (1995). Amphibians and reptiles of Yellowstone and Grand Teton national parks. Salt Lake City: University of Utah Press.

Levett-Yeats, G. A. (1914). Earth snake attacking a myna. J. Bombay Nat. Hist. Soc. 23: 371-372.

Lewis, T. H. (1946). Notes on reptiles from the state of Washington. Copeia 1946: 155-159.

Li, C. K., Wilson, R. W., Dawson, M. R. \& Krishtalka, L. (1987). The origin of rodents and lagomorphs. In Current mammalogy 1: 97-108. Genoways, H. H. (Ed.). New York: Plenum Press.

Linder, A. D. (1963). Ophiophagy by the rubber boa. Herpetologica 19: 143.

Logier, E. B. S. (1932). Some account of the amphibians and reptiles of British Columbia. Trans. R. Can. Inst. 18, Part 2(40): 311-336.

Macey, R. H. (1983). Life history notes: Charina bottae bottae (Pacific rubber boa). Food. Herpetol. Rev. 14: 19.

McKenna, M. C. \& Bell, S. K. (1997). Classification of mammals above the species level. New York: Columbia University Press.

Meng, J., Wyss, A. R., Dawson, M. R. \& Zhai, R. (1994). Primitive fossil rodent from Inner Mongolia and its implications for mammalian phylogeny. Nature (Lond.) 370: 134-136.

Merker, G. \& Merker, C. (1995). The allure of rosy boas. Reptiles 2: $48-63$.

Milner, A. C. (1986). Amphibians and squamates from the Palaeogene of England. In Studies in herpetology: 685-688. Roček, Z. (Ed.). Prague: Charles University.

Minton, S. A., Jr. (1966). A contribution to the herpetology of West Pakistan. Bull. Am. Mus. Nat. Hist. 134: 27-184.

Mora, J. M. (1991). Life history notes: Loxocemus bicolor (Burrowing python). Feeding behavior. Herpetol. Rev. 22: 61.

Mushinsky, H. R., Hebrard, J. J. \& Vodopich, D. S. (1982). Ontogeny of water snake foraging ecology. Ecology 63: 1624 1629.

Nikol'skii, A. M. (1964). Fauna of Russia and adjacent countries. Reptiles, vol. II, Ophidia. Jerusalem: Israel Program for Scientific Translations.
Nussbaum, R. A., Brodie, E. D., Jr. \& Storm, R. M. (1983). Amphibians and reptiles of the Pacific Northwest. Moscow, Idaho: University Press of Idaho.

Peabody, R. B., Johnson, J. A. \& Brodie, E. D., Jr. (1975). Intraspecific escape from ingestion of the rubber boa, Charina bottae. J. Herpetol. 9: 237.

Peterson, C. R. \& Dorcas, M. E. (1992). The use of automated data-acquisition techniques in monitoring amphibian and reptile populations. In Wildlife 2001: populations: 369-378. McCullough, D. R. \& Barrett, R. H. (Eds). London: Elsevier Applied Science.

Pitman, C. R. S. (1958). Snake and lizard predators of birds. Bull. Br. Ornithol. Club 78: 99-104.

Pough, F. H. \& Groves, J. D. (1983). Specializations of the body form and food habits of snakes. Am. Zool. 23: 443454.

Powell, F. (1914). Note on Eryx conicus. J. Bombay Nat. Hist. Soc. 23: 371 .

Prakash, V. (1988). Russell's earth boa, Eryx conicus, preying on a little brown dove, Streptopelia senegalensis. J. Bombay Nat. Hist. Soc. 85: 438 .

Pregill, G. K., Gauthier, J. A. \& Greene, H. W. (1986). The evolution of helodermatid squamates, with description of a new taxon and an overview of Varanoidea. Trans. San Diego Soc. Nat. Hist. 21: 167-202.

Rage, J.-C. (1987). Lower vertebrates from the Early-Middle Eocene Kuldana Formation of Kohat (Pakistan): Squamata. Contrib. Mus. Paleontol. Univ. Mich. 27: 187-193.

Rage, J.-C. \& Augé, M. (1993). Squamates from the Cainozoic of the western part of Europe. A review. Rev. Paléobiol., vol. spec. 7: $199-216$.

Rieppel, O. (1988). A review of the origin of snakes. Evol. Biol. 22: 37-130.

Rodríguez-Robles J. A., Bell, C. J. \& Greene, H. W. (1999) Food habits of the glossy snake, Arizona elegans, with comparisons to the diet of sympatric long-nosed snakes, Rhinocheilus lecontei. J. Herpetol. 33: 87-92.

Rodríguez-Robles, J. A. \& Leal, M. (1993). Effects of prey type on the feeding behavior of Alsophis portoricensis (Serpentes: Colubridae). J. Herpetol. 27: 163-168.

Ross, R. C. (1931). Behavior of the rubber snake. Copeia 1931: $7-8$.

Secor, S. M. \& Nagy, K. A. (1994). Bioenergetic correlates of foraging mode for the snakes Crotalus cerastes and Masticophis flagellum. Ecology 75: 1600-1614.

Shammakov, S. (1981). Reptiles of the Turkmenistan Plain. Ashkhabad, Turkmenistan: Ylym. [In Russian.]

Sharma, R. C. \& Vazirani, T. G. (1977). Food and feeding habits of some reptiles of Rajasthan. Rec. Zool. Surv. India 73: 77-93.

Shaw, C. E. \& Campbell, S. (1974). Snakes of the American West. New York: Alfred A. Knopf.

Shine, R. (1980). Ecology of the Australian death adder Acanthophis antarcticus (Elapidae): evidence for convergence with the Viperidae. Herpetologica 36: 281-289.

Shine, R., Branch, W. R., Harlow, P. S. \& Webb, J. K. (1998). Reproductive biology and food habits of horned adders, Bitis caudalis (Viperidae), from southern Africa. Copeia 1998: 391401.

Shine, R. \& Slip, D. J. (1990). Biological aspects of the adaptive radiation of Australasian pythons (Serpentes: Boidae). Herpetologica 46: 283-290.

Slip, D. J. \& Shine, R. (1988). Feeding habits of the diamond python, Morelia s. spilota: ambush predation by a boid snake. J. Herpetol. 22: 323-330.

Sorensen, D. (1988). The genus Eryx. Bull. Chicago Herpetol. Soc. 23: $21-25$.

Stebbins, R. C. (1954). Amphibians and reptiles of western North America. New York: McGraw-Hill. 
Stewart, G. R. (1977). Charina, C. bottae. Cat. Am. Amphib.Reptilia. 205.1-205.2.

Szyndlar, Z. \& Schleich, H.-H. (1994). Two species of the genus Eryx (Serpentes; Boidae; Erycinae) from the Spanish Neogene with comments on the past distribution of the genus in Europe. Amphib.-Reptilia 15: 233-248.

Tanner, V. M. \& Tanner, W. W. (1939). Notes on Charina bottae in Utah: reproduction. Great Basin Nat. 1: 27-30.

Thomas, H., Roger, J., Sen, S., Dejax, J., Schuler, M., AlSulaimani, Z., Bourdillon de Grissac, C., Breton, G., de Broin, F., Camoin, G., Cappetta, H., Carriol, R.-P., Cavelier, C., Chaix, C., Crochet, J.-Y., Farjanel, G., Gayet, M., Gheerbrant, E., Lauriat-Rage, A., Noel, D., Pickford, M., Poignant, A.-F., Rage, J.-C., Roman, J., Rouchy, J.-M., Secrétan, S., Sigé, B., Tassy, P. \& Wenz, S. (1991). Essai de reconstitution des milieux de sédimentation et de vie des primates anthropodes de l'Oligocène de Taqah (Dhofar, Sultanat d'Oman). Bull. Soc. Géol. France 162: 713-724.

Tokar, A. A. (1995). Taxonomic revision of the genus Gongylophis Wagler 1830: G. conicus (Schneider 1801) and G. muelleri Boulenger 1892 (Serpentes Boidae). Trop. Zool. 8: 347-360.
Tokar, A. A. (1996). Taxonomic revision of the genus Gongylophis Wagler 1830: G. colubrinus (L. 1758) (Serpentes Boidae). Trop. Zool. 9: 1-17.

Valls-Moraes, F. \& Yuki, R. N. (1998). Natural history notes: Anilius scytale (false coral snake). Diet. Herpetol. Rev. 29: 43-44.

Van Denburgh, J. (1922). The reptiles of western North America. II, Snakes and turtles. Occas. Pap. Calif. Acad. Sci. 10: 613-1028.

Vianey-Liaud, M. (1985). Possible evolutionary relationships among Eocene and Lower Oligocene rodents of Asia, Europe and North America. In Evolutionary relationships among rodents: a multidisciplinary analysis: 277-309. Luckett, W. P. \& Hartenberger, J.-L. (Eds). New York: Plenum Press.

Wall, F. (1911). A popular treatise on the common Indian snakes. J. Bombay Nat. Hist. Soc. 21: 1-19.

Webb, J. K. \& Shine, R. (1992). To find an ant: trail following in Australian blindsnakes (Typhlopidae). Anim. Behav. 43: 941948.

Weeks, S. E. \& Davis, C. V. (1963). Montana snakes. Montana Wildl. August-1963: 2-11.

Yingling, R. P. (1982). Lichanura, L. trivirgata. Cat. Am. Amphib.-Reptilia. 294.1-294.2. 